構造物用風洞実験設備

The Low Speed Wind Tunnel

細 見 雅 生*1, 木場和 義*2 Masao HOSOMI, Kazuyoshi KOBA

1.はじめに

近年, 大型橋梁や高層ビルなどの大型構造物の建設が さかんに行われている。これらの構造物は可とう性に 富み長周期で振動し易いため, 耐風性, 特に動的耐風性 に対する検討が必要になることが多い。現在, 耐風性に 関する研究は活発に行われているが, 風の問題は解析的 な扱いが極めて困難なことから風洞実験の役割が重要 なものになっている。当社においても, 風洞実験による 構造物の耐風性の検討の重要性に鑑み, 駒井鉄工大阪工 場に吹き出し式のエッフェル型風洞を新設した12)。風 洞の全長は約 $35 \mathrm{~m}$, 測定部の長さは $20 \mathrm{~m}$ あり, 2 次元模 型実験の他に, 今後の風洞実験や研究の動向として重要 視されている自然風のシミュレーションおよび3次元模 型実験が行えるなど境界層乱流を用いた実験に対応可 能な風洞である。本文ではこの風洞設備の概要を紹介 する。

\section{2. 基本計画}

従来から橋梁や塔の耐風性に関する試験は一様流中に おける2次元模型を用いて行われるのが一般的であった。 しかし実構造物は 3 次元的な形状をしており，また，そ れに作用する気流は時間的, 空間的に不規則に変動して いる。すなわち，構造物の風に対する挙動を的確にとら えるには構造部の3次元性や気流の乱れを考虑した試験 を実施することが重要であると考えられる。以上のこ
とから、風洞の具借すべき条件として

・自然風がシミュレートできること。

- 3 次元的の試呀が可能なこと。 が重要であると考えだ。すなわち, 境界層乱流を用いた 3次元模型試験ができる風洞を建設することを目標とし た。そのため

・自然風に相似な乱流は乱流発生装置から十分離れた 点で得られることから, 測定部の長さが十分長いこと。 - 相似性の点から, 十分に大きな縮尺の 3 次元模型が 用いられること。

を考虑して, 測定部長 $20 \mathrm{~m}$, 幅 $4 \mathrm{~m}$, 高さ $2 \mathrm{~m}$, 風速0 $10 \mathrm{~m}$ /sの規模の風洞とした。

この測定部断面では, たとえばスパン 400〜 $600 \mathrm{~m}$ の橋 梁で縮尺が $1 / 100$ ～1／150 の模型を用いることができ る。

また, 2 次元性に富む構造物の場合, 種々の面から試 験の容易な 2 次元模型試験をするために，縮流部を追加 設置することにより，風速0 25m/s の風路の設定も 可能な構造を計画した。

\section{3. 風洞設備}

3. 1 概要

本風洞は構造物の耐風性検討のための風洞実験を目的 とした低速風洞である。風洞全景をFig.1に, 風洞平面図を Fig.2に示す。また, 風洞の主要目をTable1,2に示す。

\footnotetext{
* 1 駒井鉄工楅橋梁技術部 KOMAI TEKKO Inc., Bridge Technical Dept.

*2 駒井鉄工侏橋梁技術部 KOMAI TEKKO Inc., Bridge Technical Dept. (原稀曼理: 1992 年 12 月 3 日)
} 
Fig. 2 風洞全景

(Perspective of Wind Tunnel)
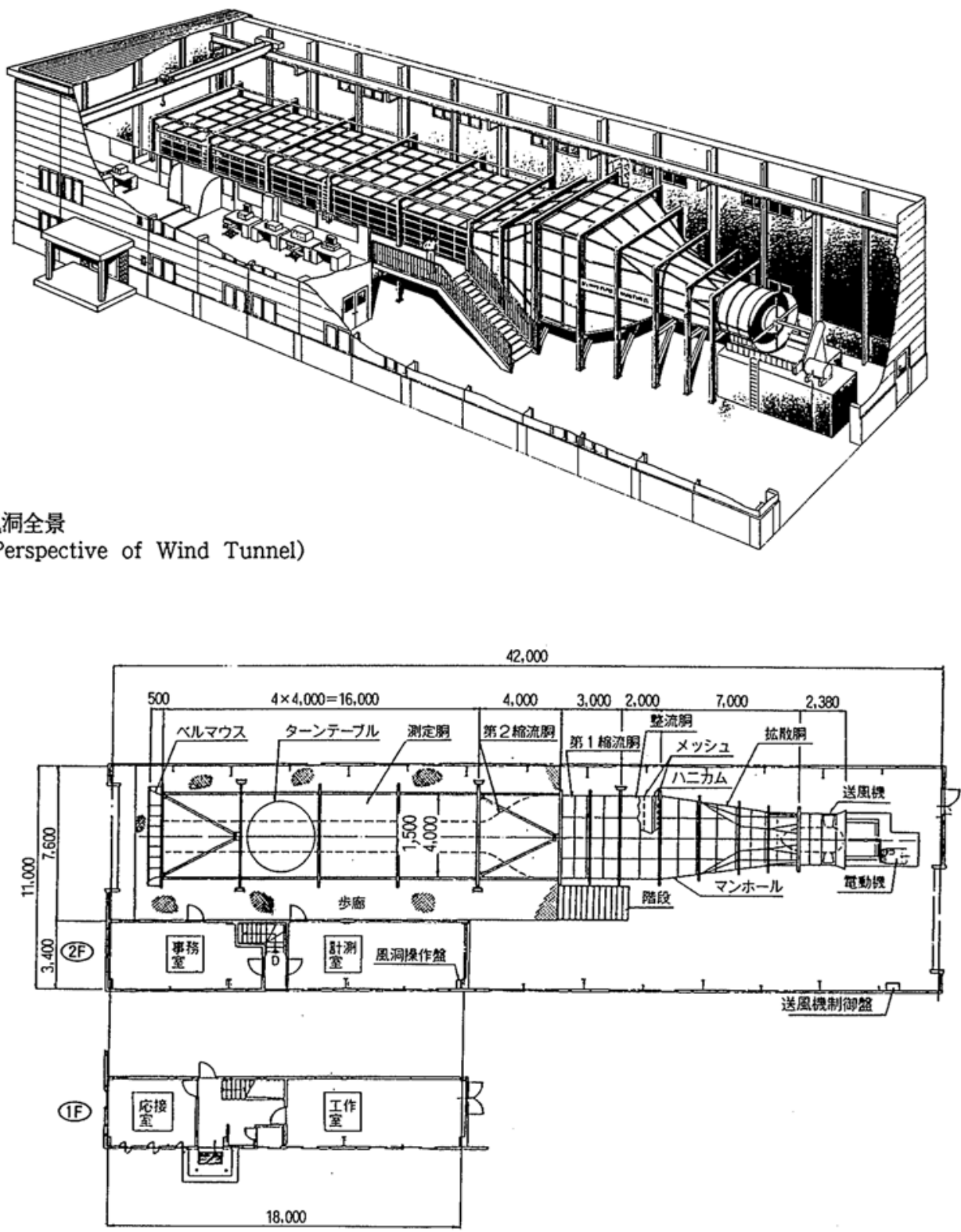

Fig. 2 風洞平面図

(Plan of Wind Tunnel)

Table 1 風洞性能

(Specifications of Wind Tunnel)

\begin{tabular}{|c|c|c|}
\hline 型 式 & \multicolumn{2}{|c|}{ 開回路式風绸 (エッッフェル型風河) } \\
\hline 测定部 & 2次元風洞 & 3次元風洞 \\
\hline $\begin{array}{l}\text { 测定部 } \\
\text { 寸 法 }\end{array}$ & $\begin{array}{c}\text { (幅) (高さ) (長さ) } \\
1.5 m \times 2.0 n \times 16 n\end{array}$ & $\begin{array}{l}\text { (幅)（高さ）(長さ） } \\
4.0 n \times 2.0 \mathrm{n} \times 20 \mathrm{n}\end{array}$ \\
\hline 風速籍用 & $0.5 \sim 25.0 \mathrm{~m} / \mathrm{s}$ & $0.5 \sim 10.8 \mathrm{~g} / \mathrm{s}$ \\
\hline 風速倔差 & $1.0 \%$ 以内 & 1.0\%以内 \\
\hline 乱九強度 & $0.5 \%$ 以内 & 0.9 \%以内 \\
\hline 静圧勾記 & $0.9 \% / n$ & $0.9 \% / \pi$ \\
\hline
\end{tabular}

Table 2 送風機・電動機性能

(Specifications of Fan and Motor)

\begin{tabular}{|c|c|c|c|}
\hline 送 & 機 & 7 & 煙 \\
\hline 型 式 & 䌷流単段送風機 & 型 式 & 直流西流機 \\
\hline 口径 & $2.5 n$ & 出 力 & $110 \mathrm{kWH}$ \\
\hline 最大風量 & $\begin{array}{l}75 \mathrm{a}^{2} / \mathrm{s}(2 \text { 次元風㚸時) } \\
87 \mathrm{a}^{2} / \mathrm{s} \text { (3次元風洞時) }\end{array}$ & 電 压 & $440 \mathrm{~V}$ \\
\hline 全 圧 & $80 \mathrm{nmAp}(770 \mathrm{rpa})$ & 回転数 & $0 \sim 1475 \mathrm{rpm}$ \\
\hline 取动方式 & ベルト掛け & 制御方式 & $\begin{array}{l}\text { サイリスタ・ } \\
\text { レオナード方式 }\end{array}$ \\
\hline
\end{tabular}




\section{2 風洞本体}

形式は吹き出し式のエッフェル型である。全長は約 $35 \mathrm{~m}$, 測定部長は $20 \mathrm{~m}$ である。拡散胴と縮流胴の間に 位置する整流胴にはアルミ製のハニカムと5枚のスクリー ン（ステンレス製金網）を設けて整流を行っている。測 定部の断面形状は側壁を取り替えることにより 2 種類の 設定が可能となっている。幅 $4.0 \mathrm{~m}$ の場合は 3 次元実験 用, 幅 $1.5 \mathrm{~m}$ の場合は 2 次元実験用として使用すること を目的とするものである (以下, 3 次元風洞, 2 次元風 洞と呼ぶ)。縮流率は 3 次元風洞で $2.5,2$ 次元風洞で 6.6 である。天井の高さは静圧勾配の影翌を考慮し, $-0.1 \mathrm{~m} \sim 0.4 \mathrm{~m}$ の範囲で移動可能な構造としている。風 速は送風機の回転数により制御し, その制御範囲は 3 次 元風洞として使用する場合は $0.5 \sim 10.8 \mathrm{~m} / \mathrm{s}, 2$ 次元風 洞として使用する場合は 0.5 25.0m/sである。

\section{3 試験装置, 計測機器}

試験装置, 計測機器として,

- 2 次元模型支持装置（回転による迎角の制御が可能）

・3分力試験装置（ロードセルとピアノ線により構成）

・電磁ダンパー

- 風速計（ピトー管式風速計, 熱線風速計, 半導体風 速センサーによる風速計)

・非接触変位計 (レーザー式, 光点位置計測式)

・微差圧計（セトラ社製）

などを整備している。

また, 計测データの処理については, データの取り込 みから計算, 図化を連続して行える機器とプログラムを 整備している。
Fig. 3にデー夕処理のための機器構成を示す。計算処 理は16ビットパソコンにより行っているが, 現在, EWS への移行を検討中である。

\section{4. 風洞の性能}

風洞の基本性能である気流特性を確認するため性能試 験を行い, 本風洞が十分な性能を有していることを確認 した。性能試験は 2 次元風洞, 3 次元風洞の両方につい て行った。試験項目は平均風速分布, 乱れ強度分布, 試 験可能な風速範囲の確認, および風洞中心軸線上の静圧 分布とした。

2 次元, 3 次元風洞の代表的な平均風速分布を Fig. 4 に示す。測定断面は標準的な一様流中の試験実施位置 とし, 2 次元風洞では第 2 縮流胴終端から $1.5 \mathrm{~m}$ 下流断 面, 3 次元風洞では第 1 縮流胴終端から $4.0 \mathrm{~m}$ 下流断面 とした。図は断面全体の平均風速に対する各測点の平 均風速の偏差（\%) を求めて等高線図に示したもので ある。2次元風洞, 3次元風洞とも偏差は, 断面周辺部の ごくわずかな部分を除いて $\pm 1 \%$ 以内であり, 本四公団 の風洞試験要領”) で示されている基準值を満足している。 平均風速分布の測定と同時に各測点における乱れ強度 を調べだ。Fig. 5 は断面内の各测点における乱れの強 度を等高線で表したものである。断面周辺部でやや高 めになっている部分も見られるが, 2 次元風洞では $0.5 \%$ 以内, 3 次元風洞では $0.9 \%$ 以内であり, 上記基準 值を十分満足している。

その他, 風速範囲, 静圧分布についても性能を確認し, 良好な結果を得だ。

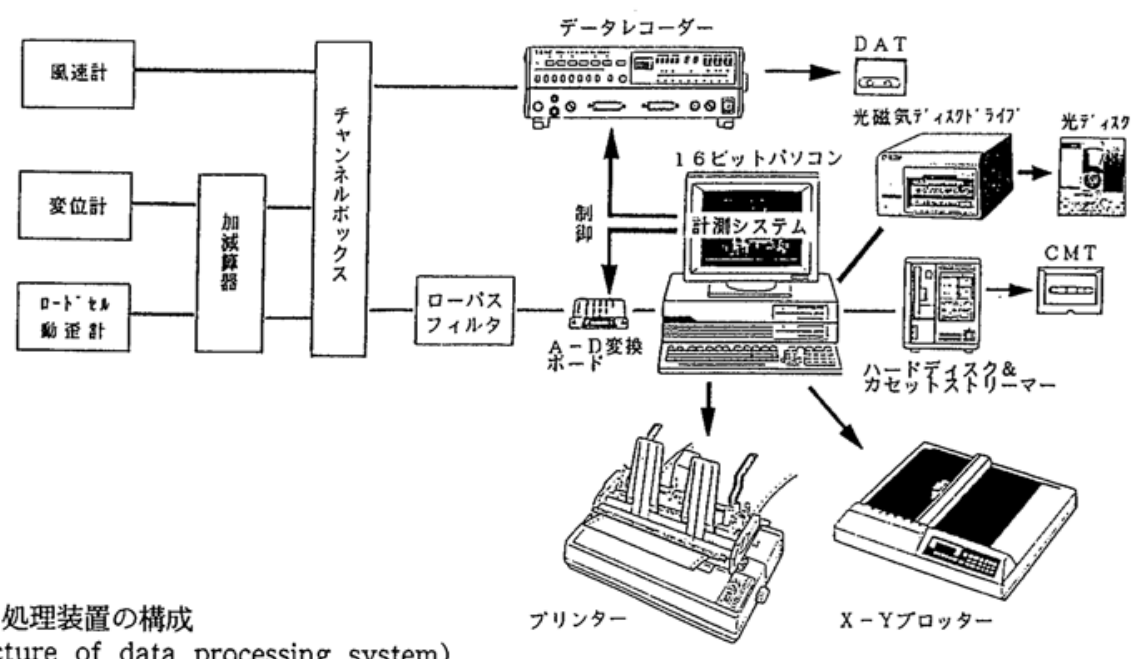

Fig. 3 デー夕処理装置の構成

(Structure of data processing system) 




（a）2次元風洞

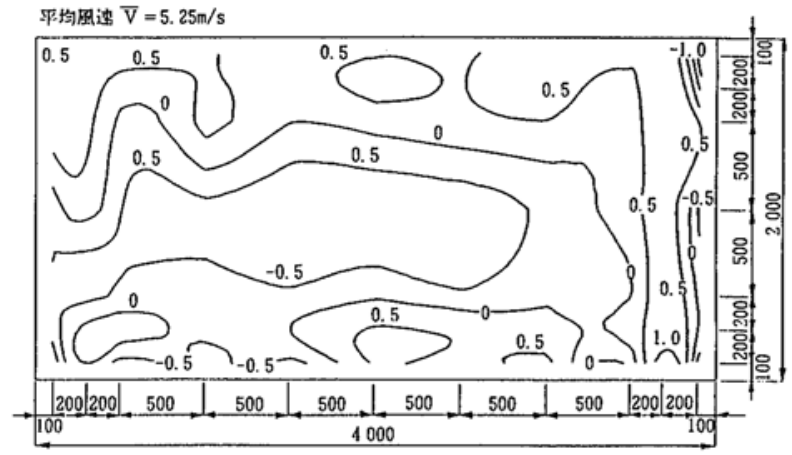

（b） 3次元風洞

Fig. 4 平均風速分布

数值は平均風速からの偏差（\%) を示す。

(Mean wind speed distributions)

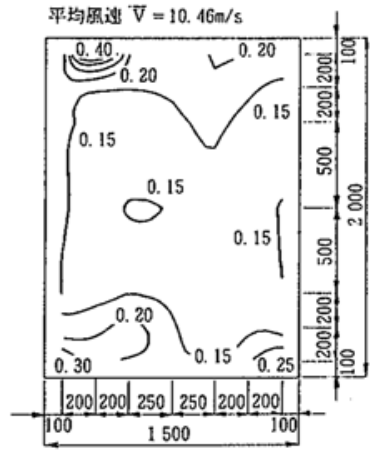

（a）2次元風洞

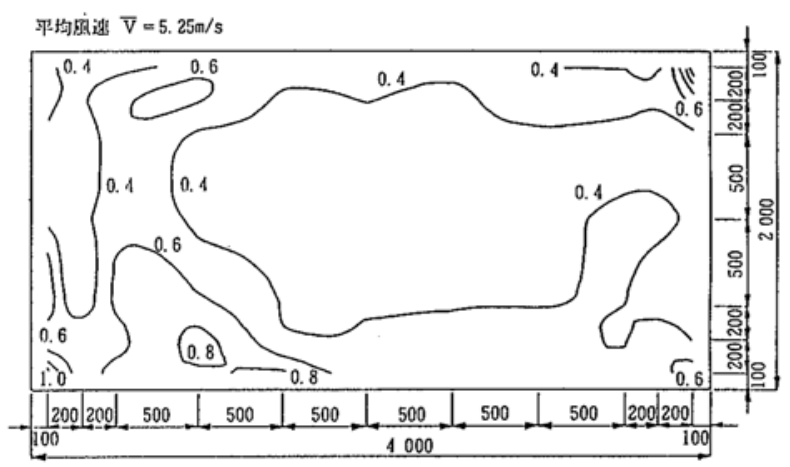

（b）3次元風洞

Fig. 5 乱れ強度 (\%) の分布

(Turbulence intensity distributions)

\section{5.あとがき}

当社大阪工場に新設された風洞実験設備とその性能に ついて概要を紹介した。ここでは報告していないが, B $\angle \mathrm{D}=2$ の矩形断面の 2 次元模型を使用した検証試験も 実施している2゙。これらの試験より本風洞設備が構造物 の耐風性検討のための風洞として十分な性能を有して いることを確認した。また，基本的な風洞試験に必要な 試験装置, 計測機器の整備は完了した。現在, 3 次元試 験, 乱流を用いた試験, 可視化など多様な要望に応えら れるよう, 継続して試験設備の整備, 拡充を行っている。 最後に, 風洞の建設の計画や性能試験などの実施にあ
たり終始懇切なご助言, ご指導を頂いた立命館大学, 小 林紘士教授に感謝の意を表します。

参考文献

1）細見雅生, 木場和義 : 風洞実験設備の紹介, 駒井技報, Vol. 9, 1990

2）木場和義, 細見雅生 : 風洞実験設備の紹介（その 2)，駒井技報，Vol.10，1991

3）本州四国連絡橋公団：風洞試験要領（1980）同解説, 1980. 6 